\title{
Influence of social media on students' academic achievement
}

\author{
Basil C.E. Oguguo ${ }^{1}$, Juliet O. Ajuonuma ${ }^{2}$, Roseline Azubuike ${ }^{3}$, Catherine U. Ene ${ }^{4}$, Florence O. Atta ${ }^{5}$, \\ Chidimma J. Oko ${ }^{6}$ \\ ${ }^{1,4,5}$ Department of Science Education, University of Nigeria, Nigeria \\ ${ }^{2}$ Department of Physical Science Education, Imo State University, Nigeria \\ ${ }^{3}$ Department of Business Education, University of Nigeria, Nigeria \\ ${ }^{6}$ Department of Educational Foundations, University of Nigeria, Nigeria
}

\begin{abstract}
Article Info
Article history:

Received Apr 2, 2020

Revised Sep 20, 2020

Accepted Oct 25, 2020

Keywords:

Academic achievement

Accounting

Information and

communication technology

(ICT)

Social media network

ABSTRACT

This study determined the influence of using social media on the academic achievement of senior secondary school students. A sample of 150 students comprising 70 males and 80 females were drawn from five schools and used for the study, this was arrived at through multi-stage sampling procedure. Social Media Questionnaire (SMQ) and Students' Accounting Achievement Proforma (SAAP) were used for data collection. The result showed that students frequently engage in social media in order to make new friends, research about their assignments and source for other educational materials, stay up to dates with latest trends and news. The finding also showed that students spend an average, 2 to 4 hours daily on social media. There was no significant influence of frequency of social media use by students on their mean academic achievements in Accounting; however, gender of students was found to have a significant influence on students' mean academic achievement in Accounting. Students should be guided properly and informed on the vulnerabilities likely to come their way if they fail to appropriately utilize the opportunities that come with having social media platforms.
\end{abstract}

This is an open access article under the CC BY-SA license.

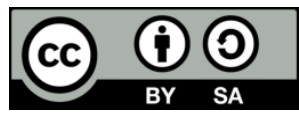

\section{Corresponding Author:}

Catherine U. Ene,

Department of Science Education, University of Nigeria,

Nsukka, Nigeria.

Email: catherine.ene@unn.edu.ng

\section{INTRODUCTION}

Information and Communication Technology (ICT) has been regarded as one of the fastest growing sectors in the world in this our contemporary times. The advancement of ICT has given rise to developments and the birthing of rapid changes in the society by shaping the global economy. Significant changes in industries, education, agriculture, medicine, business, engineering and other fields have been brought about by ICT. Within the past decades, new ICT tools such as smartphones and tablets have provided sufficient incentives for enhancing communications and entrepreneurial activity [1]. Social media is an aspect of ICT that has rapidly proliferated and penetrated almost every sector of human life. In our present days, it is almost a common practice for people to spend a major of their time making using of social networks. This is traceable to the fact that it is easy to use and it facilitates speeds and durability. Social media is fast changing the public discourse in our societies and setting trends and agendas in topics that range from the environment, education and politics to technology and the entertainment industries [2]. It is therefore obvious that the 
modern reality requires one to stay in touch and keep abreast with the latest news and trends of our time. Users of social networks, in most cases as have been reported, are a representative of the younger generation.

One of the most common means, channels or instruments for passing information across is the media [3]. In a lay man understanding, media is seen as any means of information sharing that requires the use of such media as newspapers, radios, televisions, magazines etc. according to [4], media may be seen as those means of communication through which one can be able to pass information across to a large population of persons; these means include the televisions, newspapers, and radios. More so, Webster [5] referred to media as any medium through which one is able to express, cultivate or convey information. On the other hand, social may be seen as those activities involving human environment and the individuals living and sharing resources together in the environment [3]. More so, [5] defined social as a mean through which interact together for the common good of all; it simply refers to the people or the society in general.

From the foregoing, one could refer to social media as any media circulated with the help of social interactions. Basically, social media may be referred to the cybernetic and simulated relationships, among people, organizations, and companies etc., this entails the invention, sharing or exchanging or data in the form of texts, images, and symbols. According to [6], it entails the process through which people interact by sharing, creating and exchanging information and ideas through virtual communities and networks. According to [7], social media which are internet-based applications are built on the Web 2.0 ideology and technology. Consequently, Boyd and Ellison [8] asserted that social media are built on web-based facilities that allow for the construction of public or semi-public profiles by individuals or groups of individuals.

The following have been identified as the most common social media platforms currently in use, these are; Facebook, Twitter, Whatsapp, YouTube, Wikipedia, LinkedIn, Reddit, Instagram, Pinterest etc., however, SixDegrees.com which enables people to communicate through message sharing was first introduced before the other ones; however, it could not stand the test of time despite having millions of users as registered members, as a result, it crashed out in 2000 [8]. Findings showed that other social platforms such as the Friendster and LinkedIn followed in 2002 after the collapse of SixDegrees.com. More so, between 2003 and 2006, other platforms such as the Flickr and Facebook (restricted only to Harvard) came into existence including the Hi5. Other platforms that followed included the Orkut, and MySpace emerging in 2003, YouTube, Cyworld (China), and Yahoo! 360 in 2004. "In 2005, Windows Live Spaces, Facebook (for high school and corporate networks), Ning, Asian Avenue, Bebo (relaunched) followed, while Twitter, Facebook (non-restricted), and Cyworld (USA) followed in 2006" [8]. Among these numerous social media platforms, the Facebook, Twitter, Instagram and Whatsapp have been recognized as the ones commonly used by students; in Nigeria for instance, majority of students spend an ample of their time on platforms such as the Facebook, Twitter and Whatsapp while making use of smartphones which is now a common gadgets among them; because of this reason, very many students spend 2 to 3 hours checking activities and updating their profiles on these social networks even at the peril of their educational and career pursuit [9].

The advancement of social media has taken over almost all spheres of human endeavors despites negative implications. The educational environment is equally not left out of this; people are therefore tempted to claim that that these social applications-social media carries with it the potential to further improve learning and sharing of information among learners and teachers [10]. According to [11], social media has the ability to close the gap between the learners as the teacher even down a physical distance is existing between them; in essence, it enables learners from all parts of the world to learn and work together without any hindrance(s). Miah [12] sees social media as a central path through which individuals frequently interact and share ideas despite been far apart. Social media has proven to improve communication skills, social participation and commitment, improve peer support, and ensure the realization of education based on collaborative strategies; thus, the impacts of social media on communication, learning, research and education in general cannot be overemphasized [13]. Notwithstanding, despites these benefits of social media, it appears that the negative impacts of it on students is alarming as students tend to abandon their studies in a bid to catch up with the trends and distractions of these platforms such as chatting, texting, gaming etc. [14]. Kabilan [15] noted that through social media, students learn correct spellings, sentences, pronunciations, and essay writings through the usage of Google. Mehmood and Taswir [16] found that social networking sites can become useful instruments in improving correct spellings and writings among students as it offers elasticity in learning, inspires inventive ideas and increases interpersonal interactions among students and instructors. Fodeman and Monroe [17] pointed out that the usage of Facebook has raised the level of anxiety among students as they appear to become apprehensive about being without their cell phones for a few hours.

It has been observed that all over the world, students engage themselves in using social media; spending a quality of their time on the internet by visiting various platforms. This time spent by students on social media has become of great concern to so many people, especially with the increasein the amount of time students spend online; students spend more time usually multi-tasking by visiting several sites and 
accessing volumes of contents [7, 18]. This agrees with the view of Pew Internet and American Life Project that 64 percent of teens on social media visit one or more platforms [19]. Equally, it has been noted that close to 55 percent of teenagers have created profiles on social networking sites, with 47 per cent having uploaded photos, while 14 per cent have posted videos, with nearly all of them having posted an image or comment on a platform [19]. It was reported that an average Nigerian student spends about six to seven hours on internet daily, with some spend more hours doing all night browsing [20].

Most of the factors that have been identified to be responsible for the breakthroughs experienced by social media are its universal access, convenience, functionality, and flexibility of social technologies. More so, social media platforms have the ability to influence people given such conventional media like Televisions, Radios, and Newspapers [21]. Thus, bearing in mind that the primary goal of a student is his academic achievements especially at the secondary school level since it is the stage for most career building, there is a need therefore to take their studies very serious. Academic achievement has become a thing of concern and interest to all learners, teachers, parents etc.; as a result, educational stakeholders have been working effortlessly to ensure that those factors that are capable of hindering academic achievement of students are brought under control [22].

Academic achievement is referred to the way(s) students deal with their studies as well as the actualizations of different tasks assigned to them by their teachers [23]. According to [24], academic achievement is referred to as the product of education-the extent to which students, teachers or institutions have achieved their educational objectives. Academic achievement can thus be seen as observable and measurable behaviors of an individual within a particular situation. Grade Point Average (GPA) and test results represent students' academic achievement; it is one of the current educational problems of public interest based on poor level of students' academic achievement especially in secondary schools and postsecondary schools [25]. Aina and Olanipekun [26] equally maintained that academic achievement of students both at secondary and post-secondary schools is worrisome. Furthermore, such factors as economic, social and psychological factors have been identified as likely threats to students' academic achievement [27]. These factors may have strong influences on students' academic achievement; however, the influences could vary from one person to another and from country to another. Most previous studies on academic achievement of students have focused on factors such as socio-economic background, class environment, gender differences, family educational background and teaching and learning style preferences [28]. These factors identified have been viewed as factors responsible for students' poor academic achievement in schools. It is therefore necessary to understand that no matter how well conceived a country's developmental plans may be, low academic achievement is capable of ruining everything. This therefore implies that poor academic achievement and high failure rate are indicators of underdevelopment of a society.

It has been indicated that social media networks often directly or indirectly necessitate access to information and knowledge attainment; more so, that these networks have influences on student academic achievement [29]. However, poor academic achievements in the recent times have been traced to technological developments. While technological advancement is gradually gaining dominance in the present society, the study habits of students are also fast vanishing into thin air [30]. The authors affirmed that students now lack the skills of reading and instead spend more hours on electronic media. Browsing the internet, playing with handsets and passing non-stop text messages seem to be the order of the day; this has made reading books and other pieces of written materials in a quiet or peaceful corner of libraries or homes appear an archaic idea for most school's children and adults. Students' involvement in social media activities such as making new friends and gaining access to relevant information can be channeled towards making improvements in their academic achievement, but this depends on the individual's ability and willingness to utilize the opportunity of coping with academic related stress. Utilizing these opportunities and benefits of social media networks can positively help students improve in their academic pursuits. A student who is able to creatively make waves and enormous progress in the utilization of social media can equally do exploits in his/her academic life if he is able to channel the same energy towards his/her studies [29].

According to [31], children cannot achieve success in their academics unless their expectations are raised and television sets are turned off. Apuke [32] postulated that it is a common thing these days for young people to become addicted to social media activities; as a result, they abandon their studies and shift attentions to chatting with friends, even during lectures. Additionally, many students use their phones to engage in activities which appear to be quite distracting most times. However, Bamigboye and Olusesan [33] stated that social media can be very resourceful to the academic progress of both male and female students.

Being a male or a female could simply be referred to as Gender. Gender has become a reoccurring decimal in studies that involved students' academic achievement. Gender is seen as a concept that draws out the distinctions between the males' roles and responsibilities and that of the females. Gender refers to socially constructed expectations for male and female behaviors which prescribe a division of labour and responsibilities between males and females granting of different rights and obligation to them [34]. In 
consonance with the above assertion, Cassel [35] maintained that gender refers to those social facts of being a male or a female. Several studies have been carried out on social media and gender differences and its influences on academic achievement of students. Some researchers have reported that females spend more time on social media than their male counterparts according to Matra [36]. This is in agreement with the finding of Selwyn [37] who reported that female students spend more time online than the male students; it was added with the occurrences of events, the advancement of technology in education is increasingly becoming a feminine activity.

On the other hand, researches among Chinese and British students have reported the males engage themselves in using social media more than the females as they appear to be more skilled technologically than the females [38]. It was reported by [39] that a significant difference exists between the achievement of male and female students with the male students having a better achievement than the females. In agreement with this view, Hasan and Khan [40] asserted that there is a significant influence of gender on students' academic achievement. However, these findings above are in disagreement with the findings of other researchers as [41] reported that the influence of gender on any of the dimensions of technologies studied was not significant [41]. Furthermore, no differences have been found by numerous studies on the usage of social media by males and females [42]. This aligns with the finding of [43] that gender has no significant influence on the achievement of male and female students. So there still exists a great deal of controversies among various studies on gender comparison.

Social media have become very common among students all over the world; this of course includes the schools in Enugu State where students have been seen to attending schools and classes with expensive gadgets like the mobile phones, tablets and iPods etc. with applications, facilities and software that can connect them to the internet and all forms of social media platforms, websites and so on. Evidences have shown both from the results of West African Examination Council (WAEC) of 2014 to 2018 and internal examinations that most students fail accounting. This trend could be attributed to many factors such as misuse of social media as a tool for learning, examination malpractice and environmental factors, among others. It is against this background that this study sought to investigate the influence of social media on student's academic achievement in accounting.

Various researches have shown that there have been consistent poor academic achievements among senior secondary school's students in Nigeria [25, 26, 28]. This has become a major point of concern to students, teachers, parents, guardians, as well as other stakeholders in the field of education, including researchers. And if this problem is not addressed, the issue of poor academic achievement especially in Accounting may grow worse. Already, studies have revealed that students' achievement in the use of English has been adversely affected by social media. Students tend to use short-handwriting in chatting with friends; as a result, they become used to it, this thus makes them commit errors during examination. However, this issue of poor achievement has been linked to teachers and student's characteristics such as qualification, experience, attitude or interest and gender.

Several studies on academic achievement of students focused on factors like socio-economic background, class environment, gender differences, family`s educational background, teaching and learning style among others; however, there appears to be limited studies that identified social media as a factor that could influence students' academic achievement in Accounting; furthermore, students in Enugu State are not excluded from this troubled population as the researchers noted an increase in use of mobile devices by secondary school students, quest to follow the trends and feel among and use of slangs by these students even when communicating formally with peers and elders. Based on literatures available to the researchers at the time of study, there seem to be limited empirical studies to support the fact that students' engagement in social media activities influence significantly or otherwise on academic achievement. Besides, there were also disagreements in literatures regarding the moderating influence of gender on engagement on social media and academic achievements of students. Based on these premises, the problem of this study is to ascertain to what extent social media influences students' academic achievement in Accounting in senior secondary schools in Enugu Southeast, Nigeria. The general purpose of the study is to determine the extent to which the use of social media has influenced students' academic achievement in secondary schools in Accounting. The following research questions were posed to guide the study; 1) What are the uses of social media to students? 2) What are the durations of time spent on social media by students? 3) What social media networks are mostly used by students? 4) What influence does frequency in the use of social media has on students' mean academic achievement in Accounting? 5) What influence does gender have on students' mean academic achievement in Accounting? 


\section{RESEARCH METHOD}

\subsection{Research design}

This study made use of ex-post facto research design. According to Nworgu [44], an ex-post facto research design is a type of study which tries to establish cause-effect relationships between variables of interest that cannot be manipulated. This study linked some already existing effects or observations to some variables as causative agents of the influences social media has on the academic achievements of senior secondary students. Therefore, this research design was considered appropriate for this study.

\subsection{Participants}

The study participants consist of 150 accounting students (70 males and 80 females). The participants were selected through multi-stage sampling procedure. Purposive sampling technique was used in selecting schools within the urban area where social media platforms are mostly used; and to also select five co-educational schools for proper representation of both genders. In the third stage, disproportionate stratified random sampling technique was employed in selecting the sample of students who were used for the study, from each selected school.

\subsection{Instrument for data collection}

The instruments used for data collection were Social Media Questionnaire (SMQ) and Students Accounting Achievement Proforma (SAAP). The questionnaires have two sections; section A contained demographic data of the respondents while section B consisted of three clusters: cluster A-what students use social media for consisted nine items; cluster B-duration of time spent on social media contained nine items and cluster C-frequently used social media contained eleven items. This resulted to a total of 30 items structured on a four Point Likert-type scale to seek information on the purpose of social media usage, quality of time spent on social media, frequently used social media and the impact of social media on academic performance. Students' Accounting Achievement Proforma (SAAP) was used to collect the existing terms' results and cumulative scores for previous academic sessions of the sampled students. The proforma consisted of eight columns: serial numbers, name, class, academic year, $1^{\text {st }}$ term, $2^{\text {nd }}$ term, $3^{\text {rd }}$ term and cumulative grade.

\subsection{Validity of the instrument}

The instrument was validated by three experts of research measurement and evaluation. They validators examined the items of the instruments to ensure that the items were clear and in line with the objectives of the study, as well as the appropriateness of the instruments`items in terms of the language used. Their valuable observations and corrections were used to design the final versions of the instruments which were used for data collection for the study.

\subsection{Reliability of the instrument}

The instruments were trial tested on three (3) senior secondary schools which were outside the main study area. A sample of 30 senior secondary school students in senior school two (SS2) was randomly chosen from the three (3) selected schools. The internal consistency reliability of the instruments was estimated using Cronbach Alpha method based on the collected data. The estimates of the various clusters of the instruments were calculated as follow: cluster $1=.60$; cluster $2=.62$; cluster $3=.86$. The overall reliability of the instrument gave the reliability coefficient of 0.68 .

\subsection{Method of data analysis}

Mean and standard deviations were used to answer the research questions while t-test was used to test the formulated hypotheses at 0.05 level of significance. The influence of social media on the student's academic achievement in Accounting was categorized using mean ratings; 0- $1.5=$ low level of influence; 1.6-2.5 = moderate level of influence; and 2.6- 4.0 = high level of influence.

\section{RESULTS AND DISCUSSION}

\subsection{Uses of social media}

Table 1 shows that items 1 to 6,8 and 9 have mean values between 2.6 to 4.0 ; this means that students use social media for those items statements at a high level. Item 7 has a mean rating of 2.25 which means that the use of social media in reaching out to teachers by students is in moderation. The clusters mean of 3.11 shows that generally, students use social media at a high level. The findings of this study showed that usage of social media by students is high; these social media platforms are being used by students to make new friends, chat with their friends, to upload their photos and videos, to research about their assignments and other educational materials, to stay up to date with latest trends and news, to reach out to their classmates 
for group assignments, to research about future academic career, and to discuss trending topics like Big Brother Naija, and Champions League.

The study revealed that students rarely use social media to reach out to their teachers. These findings corroborate with earlier findings by other researchers. Findings on what students use social media for agreed with the findings of [45], who found that students use social media to interact with friends, connect with classmates for online study and in discussing serious national issues. In another study carried out in Malaysia by [46], its findings are in disagreement with the findings of this study. The author found that a minority of students $(26 \%)$ use social media for academic purposes.

Table 1. Mean $(\bar{x})$ and standard deviation (SD) on the use of social media by students

\begin{tabular}{|c|c|c|c|c|c|}
\hline $\mathrm{S} / \mathrm{N}$ & Items Statement & $\mathrm{N}$ & $\bar{x}$ & SD & Decision \\
\hline 1 & I use social media to make new friends & 150 & 2.93 & 0.82 & HLU \\
\hline 2 & I chat with my friends using social media & 150 & 3.52 & 0.62 & HLU \\
\hline 3 & When I want to upload my pictures and videos, I make use of social media & 150 & 3.10 & 0.89 & HLU \\
\hline 4 & I research on my assignments and read educational articles using social media & 150 & 3.63 & 0.65 & HLU \\
\hline 5 & $\begin{array}{l}\text { I stay up to date with latest trends and news such as BBNaija, Champions League, etc. } \\
\text { with the help of social media }\end{array}$ & 150 & 2.81 & 1.03 & HLU \\
\hline 6 & When I want to research about future academic careers, I simply use social media & 150 & 3.25 & 0.68 & HLU \\
\hline 7 & I engage in social media to reach out to my teachers & 150 & 2.25 & 0.93 & MLU \\
\hline 8 & Social media help me reach out to my classmates for group assignments easily & 150 & 3.33 & 0.88 & HLU \\
\hline \multirow[t]{2}{*}{9} & I am in social media groups like Whatsapp and Facebook groups & 150 & 3.23 & 0.90 & HLU \\
\hline & Cluster Mean & 150 & 3.11 & 0.40 & HLU \\
\hline
\end{tabular}

Key: 0- 1.5 = Low Level of Use (LLU); 1.6-2.5 = Moderate Level of Use (MLU); and 2.6- 4.0 = High Level of Use (HLU). (Field work, 2020)

\subsection{Duration of time spent on social media}

The result of Table 2 shows means ratings of 2.29, 2.21, 2.15, 2.50, 2.51, 2.45 and 2.49 for Monday, Tuesday, Wednesday, Thursday, Friday, Saturday and Sunday respectively. The above result shows that students use social media for 2 to 4 hours on Mondays, Tuesdays, Wednesdays, Saturdays and Sundays. However, they use social media for up to 4 to 6 hours on Thursdays and Fridays. The cluster means of 2.37 shows that on average, students use social media for 2 to 4 hours daily.

The study showed that students spend an average, 2 to 4 hours daily on social media. However, on Mondays, Tuesdays, Wednesdays, Saturdays, and Sunday, the students spend between 0 to 2 hours on social media while they spend 2 to 4 hours on Thursdays and Fridays. These findings corroborate with earlier findings by other researchers. Findings on the duration of time students spend on social media are in agreement with the finding of [9]; the author reported that students spend 2 to 3 hours daily on social media. Chaffey's report in 2016 also corroborated with the findings of this study; Chaffey reported that students spend 2hours daily on social media. However, these findings disagreed with the findings of [47] on time spent on social media by students; they reported that students spend a lot of time, 6 to 8 hours a day on social media. These findings also disagreed with the findings of [20], who reported that students spend 6 to 7 hours daily on social media.

Table 2. Mean and standard deviation (SD) on the duration of time spent using social media by students

\begin{tabular}{cccc}
\hline Days of the Week & $\mathrm{N}$ & Mean & SD \\
\hline Monday & 150 & 2.29 & 1.14 \\
Tuesday & 150 & 2.21 & 1.10 \\
Wednesday & 150 & 2.15 & 1.17 \\
Thursday & 150 & 2.50 & 1.04 \\
Friday & 150 & 2.51 & 1.05 \\
Saturday & 150 & 2.45 & 1.10 \\
Sunday & 150 & 2.49 & 1.14 \\
Cluster Mean & 150 & 2.37 & 0.84 \\
\hline Key: $\mathrm{x}=0-1.49(0-2$ hours); $\mathrm{x}=1.50-2.49(2-4$ hours); $\mathrm{x}=2.50-3.49$
\end{tabular}

(4-6 hours); $\mathrm{x}=3.50-4.00$ (Above 6 hours) (Field work, 2020)

\subsection{Social media networks mostly used by students}

Table 3 shows that Facebook, WhatsApp and YouTube have mean ratings of 2.99, 2.95 and 2.69 respectively, which mean that these social networks have high frequency of use by the students. WeChat, Imo, Instagram, twitter, telegram, Yahoo, 2go and skype has mean ratings of 1.79, 1.67, 2.35, 2.00, 2.01, $1.73,1.67$ and 2.15 respectively; this means that usage of these social media networks by students is in 
moderation. The cluster means of $2.15(\mathrm{SD}=0.64)$ shows that overall, there is moderate frequency of use of social media networks by students.

The findings of this study also revealed that students use three social media platform most frequently; Facebook, Whatsapp and YouTube most frequently. It revealed that students visit these social media sites to get their assignments done, communicate with their peers and get information that supports their education. The findings of $[45,48,49]$ gave credence to the findings of the present study. Chinthakayala, et al. [48] pointed out that Facebook is a general social media site and is more popular among college students. However, Eke as cited in Manasi [45] pointed out the various social media sites used by students; the researchers reported that students mostly use social media sites such as Facebook and Whatsapp in interacting with friends, connecting to their classmates for online study and for discussing serious national issues which are also among the sites that are commonly accessed by the student as revealed in the present study. Maureen [49] showed that students make use of several social media platforms with Facebook, Whatsapp and Yahoo having the highest number of frequencies of usage; this is in agreement with the most frequently used social media networks revealed in this study.

Table 3. Mean and standard deviation on frequency of use of social media networks by students

\begin{tabular}{ccccc}
\hline Social Media Network & $\mathrm{N}$ & Mean & SD & Decision \\
\hline Facebook & 150 & 2.99 & 1.11 & HFU \\
WhatsApp & 150 & 2.95 & 1.19 & HFU \\
WeChat & 150 & 1.79 & .96 & MFU \\
Imo & 150 & 1.67 & .96 & MFU \\
Instagram & 150 & 2.35 & 1.19 & MFU \\
Twitter & 150 & 2.00 & .99 & MFU \\
Telegram & 150 & 2.01 & 1.03 & MFU \\
Yahoo & 150 & 1.73 & .86 & MFU \\
2go & 150 & 1.67 & .86 & MFU \\
YouTube & 150 & 2.69 & 1.14 & HFU \\
Skype & 150 & 1.81 & 1.01 & MFU \\
Cluster Mean & 150 & 2.15 & .64 & MFU \\
\hline Key: 0 - 1.5 = Low Frequency of Use (LFU); $1.6-2.5=$ Moderate Frequency of
\end{tabular}

Use (MFU); and 2.6- 4.0 = High Frequency of Use (HFU). (Field work, 2020)

\subsection{Influence of frequency of use of social media networks on student's academic achievement}

Result in Table 4 shows that most of the students (66) use social media between 2 to 4 hours daily. This is followed by those who use SMN between 4 to 6 hours per day (35), 0 to 2 hours per day (29), and least are those who used SMN above 6 hours per day (20). The result also shows that students who use SMN between 2 to 4 hours recorded the highest mean academic achievement in Accounting $(x=76.82)$, followed by those who used SMN between 0 to 2 hours $(\mathrm{x}=74.36$ ). Those who used SMN between 4 to 6 hours and Above 6 hours had mean academic achievement of 69.50 and 70.85 respectively. The result in Table 5 shows that there is no significant influence of frequency of social media use by students on their mean academic achievement in Accounting, $\mathrm{F}(3,146)=1.948, \mathrm{p} \geq 0.05$. This means that the students do not differ in their mean academic achievement in Accounting based on the frequency of use of SMN.

The findings of this study revealed that frequency of social media usage has an influence on students' achievement in Accounting. Students who use social media for 2 to 4 hours daily had the highest mean achievement in Accounting, followed by those who use social media between 0 to 2 hours. Those who use social media between 4 to 6 hours and above 6 hours had mean academic achievement of 69.50 and 70.85 respectively. This finding could be explained by the assertions made by $[15,16]$, which appear to be in agreement with the findings of the present study. Kabilan [15] found that students who use social media learn correct spelling, sentence, pronunciation, and essay writing by Googling the words into the nets. Mehmood and Taswir [16] found that social media are useful in improving correct spelling and writing among students by offering elasticity in learning, inspiring inventive ideas and increasing interpersonal interaction among students and instructors. In disagreement with the findings of this study, Ezeji [50] revealed that the rate of social media usage among students were very high and had a negative influence on the students. 
Table 4. Mean and standard deviations on influence of frequency of use of social media networks (SMN) on students' mean academic achievement in accounting

\begin{tabular}{cccc}
\hline SMN use hour per day & $\mathrm{N}$ & Mean & SD \\
\hline 0-2 hours & 29 & 74.36 & 16.15 \\
2-4 hours & 66 & 76.82 & 13.18 \\
4-6 hours & 35 & 69.50 & 16.63 \\
Above 6 hours & 20 & 70.85 & 20.24 \\
Total & 150 & 73.84 & 15.802 \\
\hline
\end{tabular}

Table 5. One-way analysis of variance (ANOVA) on the influence of frequency of social media usage by students on their mean academic achievement in accounting

\begin{tabular}{ccccccc}
\hline Source of variation & Sum of Squares & df & Mean Square & F & Sig. & Decision \\
\hline Between Groups & 1431.711 & 3 & 477.237 & 1.948 & 125 & Not Significant \\
Within Groups & 35774.222 & 146 & 245.029 & & & \\
Total & 37205.933 & 149 & & & & \\
\hline
\end{tabular}

(Field work, 2020)

\subsection{Influence of gender on student's social media usage and student's academic achievement}

Table 6 shows that the male students have a mean academic achievement of 71.12 while the female students have a mean academic achievement of 76. 23. This result shows that female students have a higher mean academic achievement compared to their male counterparts. Table 7 shows an independent t-test summary table conducted on the influence of gender on students mean academic achievement in Accounting. The result shows that a significant difference exists between the male and female students on their mean academic achievement in Accounting, $\mathrm{t}(2,148)=-1.994, \mathrm{p} \leq 0.05$. This means that the male and female students differ in their academic achievement.

The result revealed that female students have higher mean achievement in Accounting than their male counterparts. In agreement with the findings of this study, Brown [21] revealed that female students obtained better achievement scores than males. They attributed this phenomenon in line with the view that male students spend so much time on social media while the female students who are not allowed access to social media, studied harder. In disagreement with the above view, Amogne [39] found that there is a statistically significant difference between male and female students' achievement in favor of the male students. The author reported that male students have higher mean achievement in Accounting than female students.

Table 6. Mean and standard deviations of influence of gender on students' mean academic achievement in

\begin{tabular}{cccc}
\multicolumn{4}{c}{ accounting } \\
\hline Gender & $\mathrm{N}$ & Mean & SD \\
\hline Male & 70 & 71.12 & 17.42 \\
Female & 80 & 76.23 & 13.91 \\
\hline
\end{tabular}

Table 7. Summary of t-test on influence of gender on students' mean academic achievement in accounting

\begin{tabular}{ccccc}
\hline Source of variation & $\mathrm{t}$ & $\mathrm{df}$ & Sig. (2- tailed) & Decision \\
\hline Equal variances assumed & 1.994 & 2 & .048 & \multirow{2}{*}{ Significant } \\
Equal variances not assumed & -1.964 & 148 & .052 & \\
\hline
\end{tabular}

\section{CONCLUSION}

The findings of this present study revealed that senior secondary school students use social media to make new friends, chat with friends, upload their photos and videos, research about their assignments and other educational materials, stay up to date with latest trends and news, reach out to their classmates for group assignments, research about future academic career, and discuss trending topics like Big Brother Naija, and Champions League. The students spend two to four hours daily on social media; access various social media with the ones being frequently used to be Facebook, Whatsapp \& YouTube. Frequency of social media usage has influences on students' achievement in Accounting, with female students having higher mean achievement scores than male students. There is no significant influence of the frequency of social media usage by students on their mean academic achievement in Accounting. Therefore, students do not differ in their mean academic achievement in Accounting based on frequency of how they use social media. The 
second hypothesis showed that there is a significant influence of gender on students' mean academic achievement in Accounting. Therefore, male and female students differ in their academic achievement.

It is pertinent that these students do not abuse the good uses of social media, while parents and teachers encourage them to continue consuming the appropriate contents online. Teachers can also upload educational contents online in the forms of blogs and articles and have students read them in their spare times, online. The limitation encountered while conducting this study was the issue of respondents faking responses or distorting the required information by giving responses that are not entirely true, which may have slightly affected the findings of the study.

\section{ACKNOWLEDGEMENTS}

The authors express their gratitude to the secretary Post-Primary Schools Management Board, Enugu State, Nigeria. Thanks also to the principals whose schools were used for data collection and all the authors whose works were consulted during the process of this study.

\section{REFERENCES}

[1] Lagi, B. and Raja, W.D., "Mobile learning in higher education," International Journal of Research, vol. 5, no. 4, pp. 1-6, 2017.

[2] Nami, K., "Impact of ICT on entrepreneurship," First International Conference on Management, Innovation and Entrepreneurship, vol. 9, pp. 32-45, 2010.

[3] Hanks, P. (Ed.), Collins Dictionary and Thesaurus of the English Language. London: Glasgow: HarperCollins, 2014.

[4] Urdang, L. (Ed.)., Collins Online Dictionary. London: Glasgow: HarperCollins, 2014

[5] Webster, N., "Merriam-Webster Collegiate Dictionary," Springfield, Massachusetts: George \& Charles Merriam 2019. [Online]. Available: https://doi.org/10.5860/choice.31-0669

[6] Ahlqvist, T., Bäck, A., Halonen, M. and Heinonen, S., "Social media roadmaps: Exploring the futures triggered by social media," VTT Tiedotteita-Valtion Teknillinen Tutkimuskekus, p. 13, 2008

[7] Kaplan, A. M. and Haenlein, M., "Users of the world, unite! The challenges and opportunities of Social Media," Business Horizons, vol. 53, no. 1, pp. 59-68, 2010.

[8] Boyd. D.M. and Ellison, N.B., "Social network sites: definition, history and scholarship," Journal of ComputerMediated Communications, vol. 13, no. 5, pp. 210-230, 2007.

[9] Owusu-Acheaw, M. and Larson, A.G., "Use of social media and its impact on academic performance of tertiary institution students: A study of students of Koforidua Polytechnic, Ghana," Journal of Education and Practice, vol. 6, no. 6, pp. 94-101, 2015.

[10] Ferdig, M., "Sustainability leadership: co-creating a sustainable future," Journal of Change Management, vol. 7, no. 1, pp. 25-35, 2007.

[11] West D.M., "How blogs, social media and video games improve education," Governance studies: The brooking institution, Washington, 2012.

[12] Miah, M., et al., "Effects of social networking on adolescent education," Information Systems Education Journal, vol. 11, no. 3, pp. 90-100 2013.

[13] Gülbahar, Y., et al., "Usability evaluation of "web macerasi" as an instructional and evaluation method," Ankara University, Journal of Faculty of Educational Sciences, vol. 41, no. 2, pp. 209-236, 2008. [Online]. Available: https://doi.org/10.1501/EGIFAK_0000001134

[14] Omachonu, C, G. and Akanya, J., "Effects of social media on the academic achievement of students: A case study of the students of the Aayigba, Nigeria," International Journal of English Language Teaching, vol. 7, no. 5, pp. 14-23, 2019.

[15] Kabilan, M., Ahmad, N. and Jafre, M., "Facebook: An online environment for learning of English in institutions of higher Education?" The Internet and Higher Education, vol. 13, no. 4, pp. 179-187, 2010.

[16] Mehmood, S. and Taswir, T., "The effects of social networking sites on the academic performance of students in college of applied sciences," International Journal of Arts and Commerce. vol. 2, no. 1, pp. 111-125, 2013.

[17] Fodeman, D. and Monroe. M., "The impact of Facebook on our students," Teach. Lib., vol. 36, no. 5, p. $36,2009$.

[18] Rideout, V., Foehr, U., and Roberts, D., "Generation M2: Media in the lives of 8- to 18- year olds," 2010. [Online]. Available: http://www.kff.org/entmedia/upload/8010.pdf

[19] Lenhart, M. and Madden, M., "Teens, privacy and online social networks. how teens manage their online identities and personal information in the age of my space," Pew Internet \& American Life Project Report, pp. 1-45, 2007

[20] Ajewole, O.O. and Fasola, O.S., "Social network addiction among youths in Nigeria," Journal of Social Science and Policy Review, vol. 15, no. 2, pp. 72-75, 2012.

[21] Brown, S., "From vles to learning webs: the implication of web 2.0 for learning and teaching," Interactive Learning Environments, vol. 18, no. 1, pp. 1-10, 2010.

[22] Aremu, O.A and Sokan, B.O., "A multi casual evaluation of academic performance of Nigerian learners: Issues and implications for national development," An unpublished Manuscript, University of Ibadan: Ibadan, 2008.

Int. J. Eval. \& Res. Educ. Vol. 9, No. 4, December 2020: 1000 - 1009 
[23] Kimberly, B., et al., "Social networking sites affect one's academic performance adversely," 2009. [Online]. Available: http://www.scribd.com/doc/28919575/SOCIAL-NETWORKING- SITES-

[24] Ward, A., Stoker, H. W., and Murray-Ward, M., "Achievement and ability tests-Definition of the domain," Educational Measurement, vol. 2, pp. 2-5, 1996.

[25] Kolawale, C.O.O. and Dele, A., "An examination of the national policy of language education in Nigeria and its implications for the teaching and learning of the English language," Ibadan Journal of Education Studies, vol. 2, no. 1, pp. 12-20, 2012.

[26] Aina, J.K. and Olanipekun, S.S., "The influence of English language on students' academic performance in Physics Colleges of education, Asian," Academic Research Journal of Social Science and Humanities, vol. 1, no. 23, pp. 272-281, 2014.

[27] Mlambo, V., "An analysis of some factors affecting students' academic performance in an introductory biochemistry course at the University of West Indies," Carribean Teaching Scholar, vol. 1, no. 2, pp. 79-92, 2011.

[28] Aripin, R., et al., "Students' learning styles and academic performance," 22 nd Annual SAS Malysia Forum, 2008.

[29] Baldwin, T.T., Bedell, M. D. and Johnson, J.L., "The social fabric of a team- based M.B.A. program: network effects on student satisfaction and performance," Academy of Management Journal, vol. 40, no. 6, pp. 50-60, 2007.

[30] Ezema. I.J. and Ekere, J.N., "The teacher librarian and promotion of reading culture among Nigerian children," The Nigerian Library Link, 2009. [Online]. Available: http://www.scribd.com/doc/14069352/Teacher-Librarian

[31] Obama, B., "Barack Obama on libraries: Bound to the word," Keynote address at the opening general session at the ALA Annual Conference in Chicago, June 23-29, 2008. [Online]. Available: http://boulderlibrary.wordpress.com/2008/11/10/bound-to-the-word-by-barack-obama-courtesy-of-americanlibrary-association/

[32] Apuke, D.O., "The influence of social media on academic performance of undergraduate students of Taraba State University, Jalingo, Nigeria," Research on Humanities and Social Science, vol. 6, no. 19, pp. 63-72, 2016.

[33] Bamigboye, O.O. and Olusesan, A.A., "An analysis of impact of social media for learning in Eastern Cape universities, South Africa," International Journal of Educational Sciences, vol. 17, no. 3, pp. 69-75, 2017.

[34] Pollard, M.S and Morgan, S.P., "Emerging parental gender indifference, sex composition of children and the third birth," America Sociological Review, vol. 67, no. 4, pp. 600-613, 2006.

[35] Cassel, E., Gender: Sexuality. Chicago: The World Book Inc, 2007

[36] Matra, A., Willyard, J., Platt, C., and Parsons, M., "Exploring web usage and selection criteria among male and female students," Journal of Computer Mediated Communication, vol. 10, no. 3, 2005.

[37] Selwyn, N., "E-Learning or she-learning? Exploring students' gendered perceptions of education technology," British Journal of Educational Technology, vol. 38, no. 4, pp. 744-746, 2006.

[38] Li, N., and Kirkup, G., "Gender and cultural differences in Internet use: A study of China and the UK," Computers and Education, vol. 48, no. 2, pp. 301-317, 2007.

[39] Amogne, E. A., "Gender disparity analysis in academic achievement at higher education preparatory schools: Case of South Wollo, Ethipia," Educational Research and Reviews, vol. 10, no. 1, pp. 50-58, 2015.

[40] Hasan, M. and Khan, S., "Academic achievement test in English and Mathematics of secondary school students in relation to gender Differences," The International Journal of Indian Psychology, vol. 2, no. 3, pp. 155-166, 2015.

[41] Jennings, S.E. and Onwuegbuzie, A.J., "Computer attitudes as a function of age, gender, math attitude and developmental status," Journal of Educational Computing Research, vol. 25, no. 4, pp. 367-384, 2005.

[42] Bianchi, A. and Philips, J.G., "Psychological predictors of problem mobile phone use," Cyber Psychology Behavior, vol. 8, no. 1, pp. 39-51, 2005.

[43] Ajai, J. and Imoko, I., "Gender differences in English achievement and retention scores: A case of problem-based learning method," International Journal of Research in Education and Science, vol. 1, no. 1, pp. 45-50, 2015.

[44] Nworgu, B.G., Educational Research: Basic Issues and Methodology (3 ${ }^{\text {rd }}$ Ed.). Nsukka: University Trust Publishers, 2015.

[45] Manasi, G., "Impact of social media on academic performance of students," MSIS 674: Social media as a tool, University of San Francisco, pp. 1-13, 2019. [Online]. Available: https://doi.org/10.13140/RG.2.2.21427.27687

[46] Agwi, U.C and Ogwueleka, F.N., "Impact of social media on students' academic performance," International Journal of Scientific and Enginieering Research, vol. 9, no. 3, pp. 1454-1462, 2018.

[47] Chaiwat T., Nithiwadee, K. and Aungkana, S., "The impact of social media on students' time consumption outside the classroom," International Journal of Information and Education Technology, vol. 7, no. 10, pp. 753-757, 2017.

[48] Chinthakayala, K.C., Kong, J., Zhao, C. and Zhang, K., "A comparative study of three social networking websites," World Wide Web, vol. 17, no. 6, 1233-1259, 2013. [Online]. Available: https://doi.org/10.1007/s11280013-0222-8

[49] Maureen, C., "Social media and study habits of secondary school students in anambra state, Nigeria," Library Philosophy and Practice (e-journal), 2018. [Online]. Available: http://digitalcommons.unl.edu/libphilprac/2160

[50] Ezeji. P.O. and Ezeji K.E., "Effect of social media on the study habits of students of Alvan Ikoku federal college of education, Owerri," World Academy of Science, Engineering and Technology, International Journal of Education and Pedagogical Science, vol. 12, no. 1, pp. 220-224, 2018. 